\title{
Compulsory notification at skilled nursing facilities
}

\author{
Milton Luiz Gorzoni ${ }^{1 *}$, Márcia Regina Valadares Aguado², Suel Luciano Pires ${ }^{3}$, Lillan de Fátima Costa Faria ${ }^{4}$ \\ ${ }^{1}$ Adjunct Professor, Department of Internal Medicine, Faculdade de Ciências Médicas da Santa Casa de São Paulo (FCMSCSP), São Paulo, SP, Brazil \\ ${ }^{2}$ Nurse, Infection Control Committee, Dom Pedro II Geriatric and Convalescence Hospital, Irmandade da Santa Casa de Misericórdia de São Paulo, São Paulo, SP, Brazil \\ ${ }^{3}$ Lecturer, Department of Internal Medicine, FCMSCSP, São Paulo, SP, Brazil \\ ${ }^{4}$ Assistant Physician, Dom Pedro II Geriatric and Convalescence Hospital, Irmandade da Santa Casa de Misericórdia de São Paulo, São Paulo, SP, Brazil
}

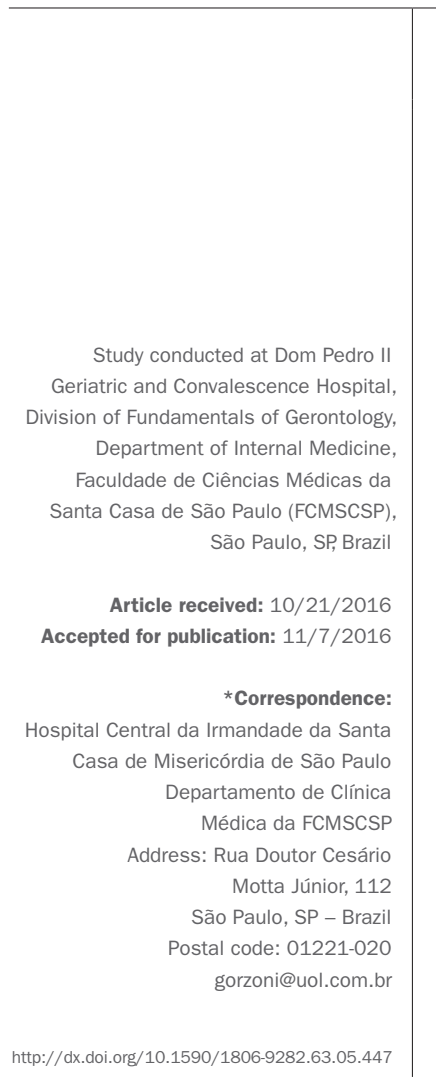

\section{SUMMARY}

Introduction: Notifiable diseases (NDs) encompass conditions of high clinical severity and/or contagious. Being closed communities, long-term care facilities (LTCF) are places that deserve attention on their own, but one might be left wondering: what is the reality of NDs at Brazilian LTCFs?

Objective: To determine the prevalence and type of NDs at large LTCF.

Method: Active search for NDs conducted by the Hospital Infection Control Committee (HICC) in 459 beds. Due to the low turnover of patients, the monthly list kept by the HICC on NDs was analyzed. Data were grouped into males and females, and into elderly (age $\geq 60$ years) and non-elderly (age $\leq 59$ years).

Results: 31 diseases in 29 patients (6.9\% of all inpatients - 19 males and $10 \mathrm{fe}-$ males): 23 cases of hepatitis C, five of hepatitis B, two of human immunodeficiency virus (HIV), and one case of renal tuberculosis. One patient with hepatitis $\mathrm{B}$ and another HIV-positive also had hepatitis C. There was no statistical significance in the comparison of the two groups with the total number of other institutionalized patients - by age and gender - for total number of NDs and cases of hepatitis $C(\mathrm{p}>0.05)$.

Conclusion: Chronic NDs and those requiring chronic treatment observed in this study suggest that Brazil needs more studies to define the dynamics of these diseases at LTCFs.

Keywords: disease notification, hepatitis, HIV, homes for the aged, tuberculosis, renal.

\section{INTRODUCTION}

Notifiable diseases (NDs) are those included in the National Notifiable Diseases Surveillance List. ${ }^{1}$ They basically include infectious diseases with high degree of clinical severity and/or highly contagious. Aspects such as the short incubation period and the capacity for wide dissemination among the exposed population define the obligation of prompt notification. A significant number of NDs require in-hospital care at some point in their clinical course, and in these cases, the Hospital Infection Control Committee (HICC) has the power to act in places without a properly structured epidemiological surveillance service.

As people are aging fast, long-term care facilities (LTCF) for the elderly should be considered another healthcare center to be approached for NDs. LTCFs are centers with characteristics of their own, regulated by specific legislation and supervised by government agencies such as those linked to sanitary surveillance. ${ }^{2}$
There are, however, problems regarding the present situation of LTCFs in Brazil.

There are high rates of bed occupancy paid for by the Brazilian Unified Health System (SUS, in the Portuguese acronym) and/or belonging to philanthropic entities, resulting in long waiting lists and occasional admission criteria that exclude syndromes that are highly prevalent among the elderly, such as urinary incontinence and dementia. These circumstances, the lack of places and professionals prepared to care for this special segment of the elderly, favor the creation of high-cost institutions, a possibility not accessible to most families, or clandestine facilities, where the risk of acts that harm the elderly is greater than in authorized LTCFs. This results in basic care schemes without adequate treatment for infectiousparasitic diseases in closed communities, such as LTCFs.

What would be the status of NDs in long-term care facilities (LTCF) for the elderly? Faced with this question, 
we investigated the pattern observed in a large nursing home in the city of São Paulo.

\section{Objective}

To determine the prevalence and type of ND at the Dom Pedro II Geriatric and Convalescence Hospital (HGCDPII) of Irmandade da Santa Casa de Misericórdia de São Paulo, comparing the information found with those reported in the Brazilian medical literature.

\section{Method}

The HGCDPII is a large LTCF that had 459 active beds in September 2008. It has a HICC since 01/18/2002 that, among its activities and according to the health surveillance legislation, ${ }^{3,4}$ actively investigates NDs.

Considering that the main characteristic of the institution evaluated is that of being a long-stay facility, that is, with low patient turnover, we opted for the analysis of the HICC on NDs based on the list issued monthly - in this case, September 2008, regardless of sex and age.

As a comparative criterion, two groups were created: group A for non-elderly institutionalized (age $\leq 59$ years) and group B for elderly institutionalized (age $\geq 60$ years) individuals. Statistical analysis used $\chi^{2}$, dividing the sample between women and men, and ages below or equal to 59 years or above or equal to 60 years, with $\alpha$ at $5.0 \%$.

Our study is part of Project no. 413/08 approved by the Research Ethics Committee of Irmandade da Santa Casa de Misericórdia de São Paulo.

\section{RESULTS}

The 421 patients ( 237 men and 184 women) hospitalized at the HGCDPII in September 2008 had a mean age of $66.2 \pm 14.9$ years (ranging from 28 to 107 years), of whom
137 were non-elderly (mean age of $49.5 \pm 7.8$ years) and 284 were elderly (mean age $74.3 \pm 10.0$ years) individuals.

Group A (non-elderly) was composed of 100 men with a mean age of $49.0 \pm 8.8$ years ( 28 to 59 years) and 37 women with a mean age of $50.9 \pm 6.3$ years (33 to 58 years), while group B (elderly) included 137 men with a mean age of $70.4 \pm 8.8$ years (60 to 101 years) and 147 women with a mean age of $77.9 \pm 9.6$ years (60 to 107 years).

The list of NDs for that month cited 31 diseases in 29 patients $(6.9 \%$ of the total number of hospitalized patients), 19 men and 10 women ( $p>0.05$ compared to the total number of institutionalized patients). These NDs, shown in Table 1, consisted of 23 hepatitis $C$ reports in patients with a mean age of $60.7 \pm 12.6$ years ( 34 to 82 years), five cases of hepatitis B in patients aged $58.0 \pm 7.3$ years (50 to 66 years), two cases of serological positivity to human immunodeficiency virus (HIV) in patients aged 55 and 66 years, and one case of renal tuberculosis (65 years old). A patient with hepatitis B (66 years old) and another positive for HIV (55 years old) also had hepatitis C. There was no statistical significance when comparing the two groups with the total number of other hospitalized patients - for age and gender - by total number of NDs and cases of hepatitis C ( $p>0.05)$.

\section{Discussion}

Since LTCFs are closed communities, they have significant potential for spread of infectious parasitic diseases such as febrile diarrhea, scabies, influenza, tuberculosis, hepatitis $\mathrm{B}$ and $\mathrm{C}^{5}$ which in some cases are included in the $\mathrm{Na}$ tional Notifiable Diseases Surveillance List. ${ }^{1}$ Their typical population ${ }^{6}$ - elderly with a high degree of physical and/ or mental dependence - presents a set of factors that contribute to the development, exacerbation or chronification

TABLE 1 Notifiable diseases divided by gender and age among individuals admitted to long-term care facility for seniors.

\begin{tabular}{|c|c|c|c|c|c|}
\hline \multirow[t]{4}{*}{ Notifiable diseases (ND)* } & \multirow[t]{4}{*}{ Total of NDs } & \multicolumn{2}{|c|}{ Group A } & \multicolumn{2}{|c|}{ Group B } \\
\hline & & \multicolumn{2}{|c|}{ Non-elderly } & \multicolumn{2}{|c|}{ Elderly } \\
\hline & & \multicolumn{2}{|c|}{ Age (mean): $49.5 \pm 7.8$ years } & \multicolumn{2}{|c|}{ Age (mean): $74.3 \pm 10.0$ years } \\
\hline & & Men & Women & Men & Women \\
\hline Hepatitis C & 23 & 05 & 04 & 10 & 04 \\
\hline Hepatitis B & 05 & 02 & 01 & $01^{* *}$ & 01 \\
\hline HIV-positive & 02 & $01^{* *}$ & - & 01 & - \\
\hline Renal tuberculosis & 01 & - & - & 01 & - \\
\hline Total of NDs & 31 & 08 & 05 & 13 & 05 \\
\hline Total number of individuals with NDs & $29^{*}$ & \multicolumn{2}{|c|}{$12(7 \mathrm{M}$ and $5 \mathrm{~F})$} & \multicolumn{2}{|c|}{$17(12 \mathrm{M}$ and $5 \mathrm{~F})$} \\
\hline Total number of institutionalized individuals & 421 & \multicolumn{2}{|c|}{$137(100 \mathrm{M}$ and $37 \mathrm{~F})$} & \multicolumn{2}{|c|}{$284(137 \mathrm{M}$ and $147 \mathrm{~F})$} \\
\hline
\end{tabular}


of these diseases ${ }^{5,7,8}$ such as compromised host defense mechanisms, decreased physiological reserve capacity, chronic, disabling and degenerative diseases, high exposure to infectious agents, and atypical clinical manifestations that delay definitive diagnosis and subsequent treatment.

It is estimated that the incidence of NDs in the Brazilian population is approximately $0.5 \%(833,123$ cases in 2004 for every 179,113,540 inhabitants). ${ }^{9}, 10$ However, we found few data on NDs in Brazilian LTCFs in the literature consulted. A search conducted on 11/15/2008 at the SciELO portal http://www.scielo.br/ using the keywords "elderly" and "institutions" obtained 41 references, of which only three reviews referred partially to infections ${ }^{11,12}$ or tuberculosis in nursing homes. ${ }^{13}$ Authors who admittedly study infections in LTCFs in Brazil also focused their publications on bacterial infections, ${ }^{14}$ anti-pneumococcal vaccine and immunity ${ }^{15}$ or tuberculosis. ${ }^{16}$ Using the keywords "diseases," "notification" and "compulsory" in the same portal and date, we found nine references in which there are no citations about LTCFs. Observations on the elderly and/or age groups were observed in four of them (two on AIDS, ${ }^{17,18}$ one on dengue fever ${ }^{19}$ and another on tetanus ${ }^{20}$ ).

Continuing the search for ND data in Brazilian LTCFs, we searched the same portal for publications on the four diseases observed in our sample.

The search for "hepatitis C," "elderly" and "institutions" did not match any articles. We did not find publications with the combined keywords "hepatitis C" and "institutions," either. A third search with the keywords "hepatitis C" and "prevalence" found 19 published studies with observations about unawareness of its actual prevalence-incidence, although with apparent predominance in young adults, ${ }^{21}$ and prevalence among health professionals of $1.7 \%$ with a $50 \%$ higher risk of contamination every five years of hospital service ${ }^{21}$ - a factor that should also be considered in LTCFs, in view of daily care with tubes, catheters and pressure ulcers, and related procedures such as laboratory tests and administration of blood products. Other publications in this research reported a prevalence of $0.3 \%$ among blood donors (mostly men aged between 26 and 45 years) ${ }^{22}$ - less than the one verified among non-elderly institutionalized patients (6.7\% of the total), possibly due to the characteristics of the two samples (healthy adults in the first and hospitalized chronic patients in the second) and prevalence of $1.5 \%$ or seven cases in a representative sample -457 inhabitants - of the adult population of a city, two of them (28.6\% of the total number of cases) aged over 60 years ${ }^{23}$ - a prevalence close to that found in our study (1.3\% of the total number of institutionalized individuals) with the difference of greater percentage of cases among the elderly ( $60.9 \%$ of the total) justified by the higher average age of the sample analyzed. There was also a reference to the association of hepatitis $\mathrm{C}$ and type II diabetes mellitus $^{24}$ - a chronic degenerative disease common in the third age and that triggers complications such as strokes and lower limb amputations, thus having potential for physical disabilities and the need for hospitalization of these individuals in LTCFs.

An equal search pattern on the same portal with the keywords "hepatitis B," "elderly" and "institutions" did not find any publication, either. The combination of the "hepatitis B" and "institutions" keywords yielded only one article on seroprevalence in patients with mental illness ${ }^{25}$ reporting results of virus prevalence in all age groups (without presenting specific details to each one) and prevalence (1.6\%) close to that observed in our sample - 5 cases from 421 hospitalized patients or $1.8 \%$ of the total. Using as keywords "hepatitis B" and "prevalence," 33 articles were located, of which only one ${ }^{26}$ would discriminate age groups with anti-HBC seroprevalence of $33.7 \%$ an age of 60 years or older.

The diagnosis of acquired immunodeficiency syndrome (AIDS) in patients over 50 years of age is not easy in clinical practice. This is due to low prevalence, although with a progressive tendency to increase in this age group, atypical symptoms, rapid progression, high mortality rate in general hospitals, and the fact that elderly patients are often not questioned about risk factors. ${ }^{17,18,27-30}$ Nevertheless, the percentage of HIV seropositivity in our sample (approximately $0.5 \%$ of inpatients) was close to that estimated for the Brazilian population between 15 and 49 years old $(0.6 \%){ }^{18,31}$ The literature consulted, however, did not present data on hospitalizations in Brazilian LTCFs.

The search on the http://www.scielo.br/ portal using as keywords "AIDS," "elderly" and "institutions" found no articles, while the combined search for "AIDS" and "institutions" yielded 16 publications, without references to LTCFs and/or age groups in them. The keywords "AIDS" and "elders" yielded nine articles with no mention of prevalence or LTCFs. Using as keywords "AIDS" and "prevalence," we found a list with 92 citations, some presenting references, at the extremes of age in the sample, to patients aged 60 years or older,,$^{17,18,30,32-37}$ with no additional information in the text. The prevalence of men with HIV was also observed in these publications, ${ }^{17,18,29-37}$ regardless of age range, which is in accordance with the two cases found in our sample. These articles presented cases without mention of the place of residence - community or LTCF. 
With similar contamination pathways, the simultaneous finding of HIV and hepatitis C in one of the institutionalized patients can be justified by the $4.5 \%$ prevalence of this combination in individuals aged from 51 to 60 years, and $1.2 \%$ prevalence between 60 and 70 years. ${ }^{38}$

The relation between aging and tuberculosis also involves atypical symptoms associated with a higher percentage of adverse reactions, significant complications and high mortality ${ }^{13,16,39-41}$ LTCFs are considered important sites for disease spread and/or recurrence, since these are closed communities with a pattern of caring for elderly patients with a high degree of physical and/or mental dependence. ${ }^{13,16}$ But again, there are few occurrences in the literature consulted that offer details on tuberculosis and LTCFs in Brazil. The same portal of previous searches using the combination "tuberculosis," "elderly" and "institutions" yielded a single review, ${ }^{13}$ which has already been cited. The cross-over of the keywords "tuberculosis" and "institutions" yielded 10 references, basically studies in hospitals and institutions for specific treatment of the disease, also with two reviews on scientific production related to tuberculosis $^{42,43}$ - without LTCFs being cited. Likewise, the keywords "tuberculosis" and "elderly" yielded only six articles, four linked to the elderly in the community ${ }^{39-41,44}$ and two reviews, ${ }^{13,16}$ already mentioned above and which cited LTCFs solely due to the risk of local spread. Most references - 70 publications - were found with the keywords "tuberculosis" and "prevalence," but mostly related to children, young adults, students and health professionals, indigenous peoples and diagnostic methodologies. The main focus of these publications was to analyze the pulmonary form of tuberculosis, with a significant number of studies on the relation between HIV and tuberculosis and on multiresistant microbacteria. Articles with data that allow comparison with our study comment that mortality due to the pulmonary form, regardless of age, is 8.5 times greater than the extrapulmonary form (possible justification of the extrapulmonary location in the only case of this series), with a risk of death 2.3 times higher in the elderly than in young adults (a possible cause of the low percentage of cases found $-0.2 \%$ of the total number of institutionalized patients) and a prevalence of $11.2 \%$ in patients aged 60 years or older, with a tendency to fall (another plausible explanation for the low prevalence in our study). ${ }^{45-47}$ Considering the parallelism between LTCFs and psychiatric hospitals - in the common feature regarding hospitalization for long periods - there is only one publication ${ }^{48}$ on pulmonary tuberculosis in $6.8 \%$ of hospitalized psychiatric patients, predominantly between 39 and 53 years of age, a fact not observed in our sample.

\section{Conclusion}

As most NDs present high clinical severity and/or are highly contagious, a significant number of cases are resolved at sites prior to LTCF. Finding in our study chronic NDs and/or NDs requiring chronic and sometimes expensive treatment, is therefore justified. Considering the rapid aging of the Brazilian population, which will increase the demand for beds in LTCFs, more attention and publications on NDs in LTCFs will be necessary.

\section{Conflict of interest}

The authors declare no conflict of interest.

\section{Resumo}

Notificação compulsória em instituição asilar

Introdução: Doenças de notificação compulsória (DNC) abrangem quadros de alta gravidade clínica e/ou de contágio. Sendo comunidades fechadas, instituições de longa permanência para idosos (ILPI) são locais que merecem atenção quanto a elas. Mas qual seria a realidade das DNC em ILPI brasileiras?

Objetivo: Determinar prevalência e tipo de DNC em ILPI de grande porte.

Método: Busca ativa de DNC pela Comissão de Controle de Infecção Hospitalar (CCIH) em 459 leitos. Em razão da baixa rotatividade de pacientes, analisou-se lista mensal da CCIH sobre DNC. Dividiram-se os dados entre homens e mulheres e entre idosos (idade $\geq 60$ anos) e não idosos (idade $\leq 59$ anos).

Resultados: 31 doenças em 29 pacientes (6,9\% do total de internados - 19 homens e 10 mulheres): 23 casos de hepatite $\mathrm{C}$, cinco de hepatite $\mathrm{B}$, dois de positividade sorológica ao vírus da imunodeficiência humana (HIV) e um caso de tuberculose renal. Um paciente com hepatite B e outro com HIV positivo eram também portadores de hepatite C. Não houve significância estatística quando foram comparados os dois grupos com o total dos outros internados - por idade e gênero - pelo total de DNC e nos casos de hepatite $C(p>0,05)$.

Conclusão: Pesquisa em 15/11/2008 no portal http://www. scielo.br/não detectou casuísticas em ILPI, exceto por revisões sobre tuberculose. DNC de caráter e/ou tratamento crônico observadas neste estudo sugerem a necessidade de maior número de publicações para definir a dinâmica dessas doenças em ILPI brasileiras.

Palavras-chave: hepatite, HIV, instituição de longa permanência para idosos, notificação de doenças, tuberculose renal. 


\section{References}

1. Brasil - Secretaria de Vigilância em Saúde. Portaria $\mathrm{N}^{\circ} 5$, de 21 de fevereiro de 2006. Inclui doenças na relação nacional de notificação compulsória, define doenças de notificação imediata, relação dos resultados laboratoriais que devem ser notificados pelos Laboratórios de Referência Nacional ou Regional e normas para notificação de casos. Diário Oficial da União - Seção 1, N. 38 página 34, 22/02/2006. [cited 2008 Dec 5]. Available from: http://bvsms.saude. gov.br/bvs/saudelegis/svs/2006/prt0005_21_02_2006_comp.html.

2. Brasil. Ministério da Saúde, Agência Nacional de Vigilância Sanitária. Resolução RDC n 283, de 26 de setembro de 2005. Aprova o Regulamento Técnico que define normas de funcionamento para as Instituições de Longa Permanência para Idosos. Diário Oficial da União; Poder Executivo, de 27/09/2005 [cited 2008 Dec 5]. Available from: http://bvsms.saude.gov.br/ bvs/saudelegis/anvisa/2005/res0283_26_09_2005.html.

3. Brasil. Ministério da Saúde, Agência Nacional de Vigilância Sanitária Portaria No. 196, de 24 de junho de 1983 [cited 2008 Dec 26]. Available from: http://e-legis.anvisa.gov.br/leisref/public/showAct.php?id=1085.

4. Brasil. Ministério da Saúde, Agência Nacional de Vigilância Sanitária Portaria $N^{\circ}$. 930, de 27 de agosto de 1992 [cited 2008 Dec 26]. Available from: http://e-legis.anvisa.gov.br/leisref/public/showAct.php?id=490.

5. Yoshikawa TT, Norman DC. Infection control in long-term care. Clin Geriatr Med. 1995; 11(3):467-80.

6. Chaimowicz F, Greco DB. Dinâmica da institucionalização de idosos em Belo Horizonte, Brasil. Rev Saúde Pública. 1999; 33(5):454-60.

7. Richards C. Infections in residents of long-term care facilities: an agenda for research. Report of an expert panel. J Am Geriatr Soc. 2002; 50(3):570-6.

8. High KP, Bradley SF, Gravenstein S, Mehr DR, Quagliarello VJ, Richards C, et al. Clinical practice guideline for the evaluation of fever and infection in older adult residents of long-term care facilities: 2008 update by the Infectious Diseases Society of America. Clin Infect Dis. 2009; 48(2):149-71.

9. Brasil - Ministério da Saúde - Série histórica de óbitos e casos de Doenças de Notificação Compulsória no Brasil (1980 - 2005) [cited 2008 Dec 28]. Available from: http://portal.saude.gov.br/portal/saude/visualizar_texto.cfm?idtxt=25340.

10. Brasil. Ministério do Planejamento, Orçamento e Gestão, Instituto Brasileiro de Geografia e estatística - Projeção da População do Brasil por sexo e idade: 1980-2050 - Revisão 2008 [cited 2008 Dec 28]. Available from: ftp://ftp.ibge. gov.br/Estimativas_Projecoes_Populacao/Estimativas_1980_2010/.

11. Gorzoni ML, Pires SL. Long-term care elderly residents in general hospitals. Rev Saúde Pública. 2006; 40(6):1124-30.

12. Gorzoni ML, Pires SL. Aspectos clínicos da demência senil em instituições asilares. Rev Psiquiatr Clin. 2006; 33(1):18-23

13. Vendramini SHF, Villa TCS, Gonzales RIC, Monroe AA. Tuberculose no idoso: análise do conceito. Rev Latinoam Enferm. 2003; 11(1):96-103.

14. Villas Boas PJF, Ferreira ALA. Infecção em idosos internados em instituição de longa permanência. Rev Assoc Med Bras. 2007; 53(2):126-9.

15. Brandão AP, de Oliveira TC, de Cunto Brandileone MC, Gonçalves JE, Yara TI, Simonsen V. Persistence of antibody response to pneumococcal capsular polysaccharides in vaccinated long term-care residents in Brazil. Vaccine. $2004 ; 23(6): 762-8$

16. Chaimowicz F. Age transition of tuberculosis incidence and mortality in Brazil. Rev Saúde Pública. 2001; 35(1):81-7.

17. Araújo VLB, Brito DMS, Gimeniz MT, Queiroz TA, Tavares CM. Características da Aids na terceira idade em um hospital de referência do Estado do Ceará, Brasil. Rev Bras Epidemiol. 2007; 10(4):544-54.

18. Santos NJS, Tayra A, Silva SR, Buchalla CM, Laurenti R. A Aids no Estado de São Paulo. As mudanças no perfil da epidemia e perspectivas da vigilância epidemiológica. Rev Bras Epidemiol. 2002; 5(3):286-310.

19. Lima VLC, Figueiredo LTM, Correa Filho HR, Leite OF, Rangel O, Vido AA, et al. Dengue: inquérito sorológico pós-epidêmico em zona urbana do Estado de São Paulo (Brasil). Rev Saúde Pública. 1999; 33(6):566-74.

20. Litvoc J, Leite RM, Katz G. Aspectos epidemiológicos do tétano no Estado de São Paulo (Brasil), 1989. Rev Inst Med Trop São Paulo. 1991; 33(6):477-84.

21. Ciorlia LAS, Zanetta DMT. Hepatitis C in health care professionals: prevalence and association with risk factors. Rev Saúde Pública. 2007; 41(2):229-35.

22. Valente VB, Covas DT, Passos ADC. Marcadores sorológicos das hepatites B e C em doadores de sangue do Hemocentro de Ribeirão Preto, SP. Rev Soc Bras Med Trop. 2005; 38(6):488-92.

23. Fagundes GD, Bonazza V, Ceretta LB, Back AJ, Bettiol J. Detection of the Hepatitis C virus in a population of adults. Rev Latinoam Enferm. 2008; 16(3):396-400.

24. Parolin MB, Réa R, Vargas RM, Almeida ACR, Baldanzi GR, Lopes RW. Prevalência de infecção pelo vírus da hepatite $\mathrm{C}$ em pacientes com diabetes melito tipo 2. Arq Gastroenterol. 2006; 43(2):77-80.
25. Souza MM, Barbosa MA, Borges AMT, Daher RR, Martins RMB, Cardoso DDP. Soroprevalência da infecção pelo vírus da hepatite B em portadores de doença mental. Rev Bras Psiquiatr. 2004; 26(1):35-8.

26. Gaze R, Carvalho DM, Werneck GL. Soroprevalência das infecções pelos vírus das hepatites A e B em Macaé, Rio de Janeiro, Brasil. Cad Saúde Pública. 2002; 18(5):1251-9.

27. Gorzoni ML, Guimarães R, Lima CAC. Síndrome de imunodeficiência adquirida (AIDS) em pacientes acima de 50 anos de idade internados em um hospital geral. Folha Méd. 1993; 107(5/6):191-4.

28. Melo MR, Gorzoni ML, Melo KC, Melo E. Síndrome da imunodeficiência adquirida no idoso. Diagn Tratamento. 2002; 7(2):13-7.

29. Pottes FA, Brito AM, Gouveia GC, Araújo EC, Carneiro RM. Aids e envelhecimento: características dos casos com idade igual ou maior que 50 anos em Pernambuco, de 1990 a 2000. Rev Bras Epidemiol. 2007; 10(3):338-51.

30. Nobre V, Braga E, Rayes A, Serufo JC, Godoy P, Nunes N, et al. Opportunistic infections in patients with aids admitted to an university hospital of the Southeast of Brazil. Rev Inst Med Trop São Paulo. 2003; 45(2):69-74

31. Fonseca MGP, Bastos FI. Twenty-five years of the AIDS epidemic in Brazil: principal epidemiological findings, 1980-2005. Cad Saúde Pública. 2007; 23(Supl 3):S333-43.

32. Turchi MD, Pannuti CS, Sumita LM, Vilas Boas LS, Weinberg A, Stavale JN, et al. Infecção pelo citomegalovírus em pacientes com síndrome da imunodeficiência adquirida (AIDS): relações clínico-virológicas e anatomopatológicas. Rev Inst Med Trop São Paulo. 1991; 33(4):243-50.

33. Dias RMDS, Mangini ACS, Torres DMAGV, Vellosa SAG, Silva MIPG, Silva $\mathrm{RM}$, et al. Ocorrência de Strongyloides stercoralis em pacientes portadores da síndrome de imunodeficiência adquirida (AIDS). Rev Inst Med Trop São Paulo. 1992; 34(1):15-7

34. Fernandes OFL, Costa TR, Costa MR, Soares AJ, Pereira AJSC, Silva MRR Cryptococcus neoformans isolados de pacientes com AIDS. Rev Soc Bras Med Trop. 2000; 33(1):75-8

35. Colombrini MRC, Dela Coleta MF, Lopes MHBM. Fatores de risco para a não adesão ao tratamento com terapia antiretroviral altamente eficaz. Rev Esc Enferm USP. 2008; 42(3):490-5.

36. Miziara ID, Araújo Filho BC, La Cortina RC, Romano FR, Lima AS. Rinossinusite crônica em pacientes infectados pelo vírus da imunodeficiência humana: avaliação clínica e radiológica. Rev Bras Otorrinolaringol. 2005; 71(5):604-8.

37. Cavassani VGS, Andrade Sobrinho J, Homem MGN, Rapoport A. Candidíase oral como marcador de prognóstico em pacientes portadores do HIV. Rev Bras Otorrinolaringol. 2002; 68(5):630-4.

38. Mendes-Correa MC, Barone AA, Cavalheiro N, Tengan FM, Guastini C Prevalence of hepatitis B and $\mathrm{C}$ in the sera of patients with HIV infection in São Paulo, Brazil. Rev Inst Med Trop São Paulo. 2000; 42(2):81-5.

39. Cantalice Filho JP, Sant'Anna CC, Bóia MN. Clinical aspects of pulmonary tuberculosis in elderly patients from a university hospital in Rio de Janeiro, Brazil. J Bras Pneumol. 2007; 33(6):699-706.

40. Cavalcanti ZR, Albuquerque MFPM, Campello ARL, Ximenes R, Montarroyos $\mathrm{U}$, Verçosa MKA. Characteristics of elderly tuberculosis patients in Recife, Brazil: a contribution to the tuberculosis control program. J Bras Pneumol. 2006; 32(6):535-43

41. Cantalice Filho JP, Bóia MN, Sant'Anna CC. Analysis of the treatment of pulmonary tuberculosis in elderly patients at a university hospital in Rio de Janeiro, Brazil. J Bras Pneumol. 2007; 33(6):691-8.

42. Kritski AL, Villa TS, Trajman A, Silva JRL, Medronho RA, Rufino-Netto A Two decades of research on tuberculosis in Brazil: state of the art of scientific publications. Rev Saúde Pública. 2007; 41(1):9-14.

43. Fabro AT, Yoo HHB, Queluz YHAT. Profile of research published in the annals of the Brazilian Pulmonology and Phthisiology Conferences held over the last twenty years. J Bras Pneumol. 2006; 32(4):309-15.

44. Silva VL, Leal MCC, Marino JG, Marques APO. Associação entre carência social e causas de morte entre idosos residentes no Município de Recife, Pernambuco, Brasil. Cad Saúde Pública. 2008; 24(5):1013-23.

45. Façanha MC. Evolution of tuberculosis-related mortality in Fortaleza, Brazil from 1980 to 2001. J Bras Pneumol. 2006; 32(6):553-8.

46. Antunes JL, Waldman EA. Tuberculosis in the twentieth century: time-series mortality in São Paulo, Brazil, 1900-97. Cad Saúde Pública. 1999; 15(3):463-76.

47. Silveira MPT, Adorno RFR, Fontana T. Profile of patients with tuberculosis: evaluation of the Brazilian national tuberculosis control program in Bagé, Brazil. J Bras Pneumol. 2007; 33(2):199-205.

48. Costa HCG, Malaspina AC, Mello FAF, Leite CQF. Tuberculosis in a Psychiatric Hospital in the state of Goiás, Brazil. J Bras Pneumol. 2006; 32(6):566-72. 